\title{
Design And Development Of Sales E-Monitoring Information System \\ Case Study : PT. Pratama Inti Distribusindo
}

\author{
Nicken Litan Margareta ${ }^{1 *}$, Amesanggeng $\mathbf{P}^{2)}$ \\ 1))Universitas Buddhi Dharma \\ 2) Universitas SatyaGama \\ Jl. Imam Bonjol No. 41 Karawavi Ilir, Tangerang- Indonesia \\ Jl. Kamal Raya No. 2A Cengkareng, Jakarta - Indonesia \\ 1)th3violet95@yahoo.com \\ 2)ames@gmail.com
}

\begin{tabular}{|c|c|}
\hline Article history: & Abstract \\
\hline $\begin{array}{l}\text { Received } 10 \text { August 2018; } \\
\text { Revised } 16 \text { August } 2018 ; \\
\text { Accepted } 25 \text { August } 2018 ; \\
\text { Available online } 19 \text { September } 2018\end{array}$ & \multirow{6}{*}{$\begin{array}{l}\text { We must recognize the development of technology at this time has developed very } \\
\text { rapidly in this era of globalization. Moreover, the development of internet-based } \\
\text { computer technology. By using the internet we can search for the information we } \\
\text { need from around the world quickly and accurately. However, there are still many } \\
\text { companies in Indonesia that have difficulty in implementing computerized systems } \\
\text { within the company, especially in internet-based information systems. From the } \\
\text { research conducted, there are several weaknesses in the processing of reports that } \\
\text { occur, namely it takes a long time to make a form, record the transactions and also } \\
\text { take a lot of paper / media recording. In addition, there is no computerized system } \\
\text { dedicated to this process. With the creation of a system of making reports with this } \\
\text { method, it is expected to assist in generating reports and checking jobs faster and } \\
\text { more accurately. After the design, manufacture, and testing of the application } \\
\text { application and inventory inventory program, conclusions can be drawn, namely } \\
\text { more company performance efficient and prone to errors if data entry is incorrect. } \\
\text { In implementing the new system, it is expected to run smoothly. }\end{array}$} \\
\hline Keywords: & \\
\hline $\begin{array}{l}\text { E-Goverment } \\
\text { Information Technology }\end{array}$ & \\
\hline Eficiency & \\
\hline nce & \\
\hline & \\
\hline
\end{tabular}

\section{INTRODUCTION}

At this time information development has developed very rapidly, therefore many companies have used information systems to improve their businesses. To improve a company's business is by building a good information system, and the requirement to build a good information system that is the speed and accuracy to obtain the information needed. A computer is a tool that can store data, process data, and provide desired information accurately and accurately that is useful for the company to progress its business.

In the process of development, a company needs a monitoring system for good sales so that the information data obtained can be maximized or even lost/difficult to find if the data is needed by the parties needed to make a decision. If the sales e-Monitoring system cannot be managed properly, it will cause various kinds of problems that can disrupt the activities or activities of the company. Therefore, it is very important for the company to maintain these systems. PT. Pratama Inti Distribusindo still does not use a computerized system for monitoring activities in its company, the monitoring that they do is still done manually so that it results in slow performance of employees in processing data, both transaction data and related documents in the sales carried out by the company. Besides that, it takes a long time to find the data needed to compile reports needed by the leadership because the data is stored manually and not computerized.

With the purpose and benefits of building this system are:

1. To find out the sales monitoring system at PT. Pratama Inti Distribusindo, which will provide sales system solutions at PT. Pratama Inti Distribusindo is computerized

2. To find out whether the system designed is able to monitor the level of sales at PT. Pratama Inti Distribusindo.

3. To find out the current system to be able to produce fast and accurate reports.

\footnotetext{
${ }^{*}$ Corresponding author
} 


\section{RELATED WORKS/LITERATURE REVIEW (OPTIONAL)}

\section{Monitoring}

Monitoring is monitoring that can be explained as awareness about what you want to know, high-level monitoring is done so that you can make measurements through time that shows the movement towards the goal or away from it [1].

"Monitoring is an activity of observing the implementation of programs and projects in the running time, and trying to correct mistakes so that at the end of the completion, the programs and projects are expected to be implemented correctly".

Monitoring is an activity to observe the progress of the implementation of a program or project. There is one plan followed by implementation.

From the definition above, describes there are 4 (four) keywords in the characteristics of monitoring . The four (4) are:

1. Gather development data

2. Observing implementation

3. in the current time

4. Fix errors or irregularities

In general there are 2 (two) types of monitoring, namely monitoring aspects of the process, and monitoring aspects of the results (input)

1. Monitoring aspects of the process

The process is a bridge to produce output. From the use of input processed it produces output. The right choice of process and able to utilize input efficiently, is a problem that must be considered in the management team. Process aspect monitoring is a job to observe whether the planned work process can run well or not. Process aspect monitoring is concentrated on observation, functioning or non-functioning of the organization, management procedures and other aspects that have been established.

2. Monitoring aspects of output

Monitoring aspects of output is focused on observing the development of achievement of output of a good planning, from the beginning must set targets or outputs and stages of achievement. On the X month, or the Xth quarter, or the Xth year, the outputs of Y, Y1, Y2 and so on will be achieved

\section{Sales Concept}

Sales are "Revenues derived from the sale of company products, are presented after deducting sales discounts and sales returns [2].

Net sales are the difference between sales made in cash and credit with sales returns and sales discounts [3]. "Selling is the science and art of personal influence carried out by sellers to invite others to be willing to buy goods or services offered" [4]. Based on the above explanation it can be concluded that "Sales are the purchase of something (goods or services) from one party to another by obtaining compensation from the party".

The general purpose of sales owned by the company [4], namely:

1. Get a certain profit.

2. Achieve a certain sales volume.

3. Support the company's growth.

In general there are two types of sales, namely cash sales and credit sales. But actually, sales have four types of sales, namely cash sales, credit sales, installment sales, and consignment sales. Usually the general public defines the meaning of credit sales and the same installments but in fact it is different.

The following is a classification of sales according [5]

1. Sales in cash Cash sales are carried out by the company by requiring the buyer to pay the price of the goods first before the goods are delivered by the company to the buyer.

2. Sales on credit Credit sales are carried out by the company by sending goods according to orders received from the buyer and for a certain period of time, the company has a bill to the buyer.

3. Installment sales Installment sales are the delivery of the seller's product to the buyer by receiving down payment, and the remainder in the form of installments for several years.

4. Consignment Sales Consignment sales are situations in which the holder of the supply of goods acts as an agent for the real owner. 
III. METHODS

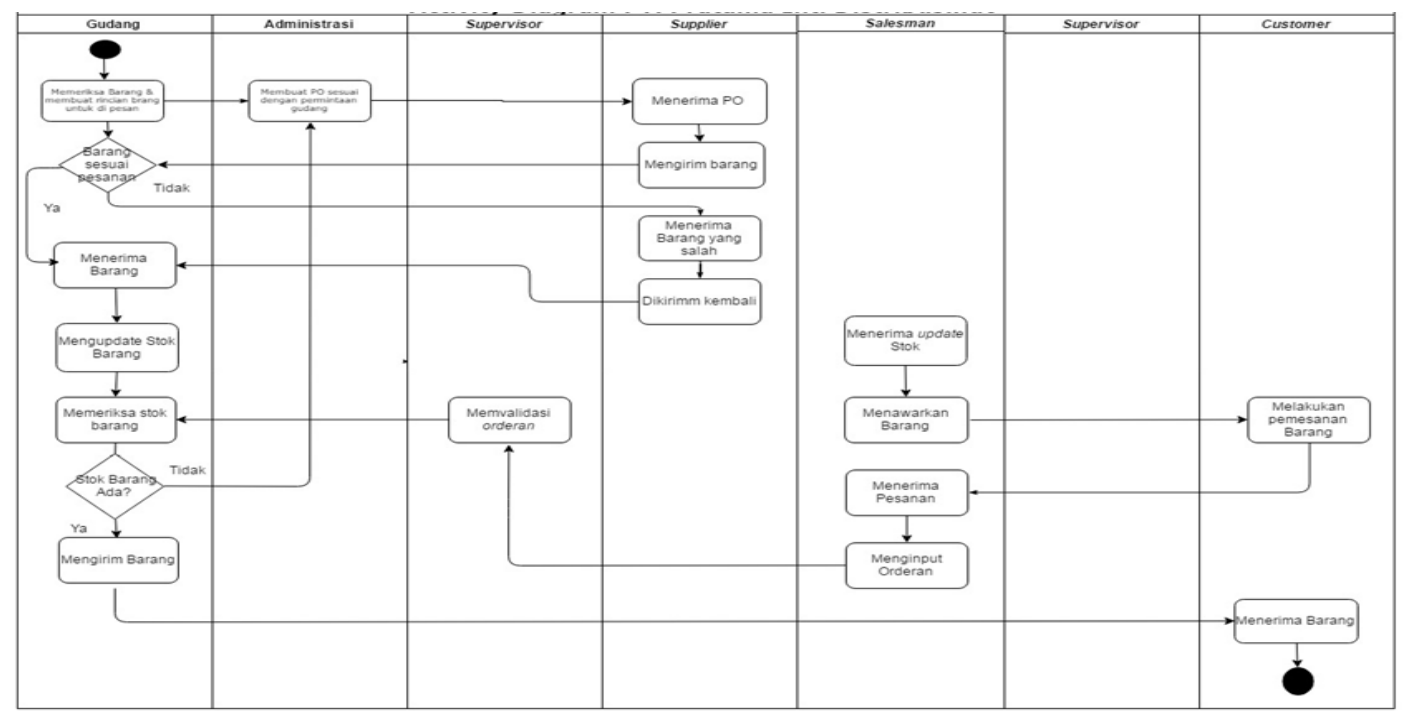

Fig 1. Activity Diagram on Going Process

The following are procedures related to the PT system. Pratama Inti Disribusindo is currently running:

1. The warehouse section checks inventory of goods according to customer orders.

2. Make details of the items that will be ordered to the admin so that the ordering PO is quickly processed.

3. The admin section will make a PO order then send the order to the supplier.

4. The warehouse section checks / updates the inventory in accordance with the order.

5. Receive ordered items and then record items entering the inventory card (stock card).

6. Make a record of every incoming and outgoing goods.

7. Conduct periodic Stock Holding process.

8. Make an inventory report.

9. Salesman accepts orders from customers.

10. The salesman inputs the customer's request.

11. The supervisor validates and verifies orders that have been inputted.

12. The warehouse section checks available stock items.

13. The administration section receives goods reports already available.

14. The administration section creates \& prints travel documents and sales invoices, then submits them to the warehouse.

15. Warehouse parts deliver goods.

16. The warehouse section reports the goods out. 


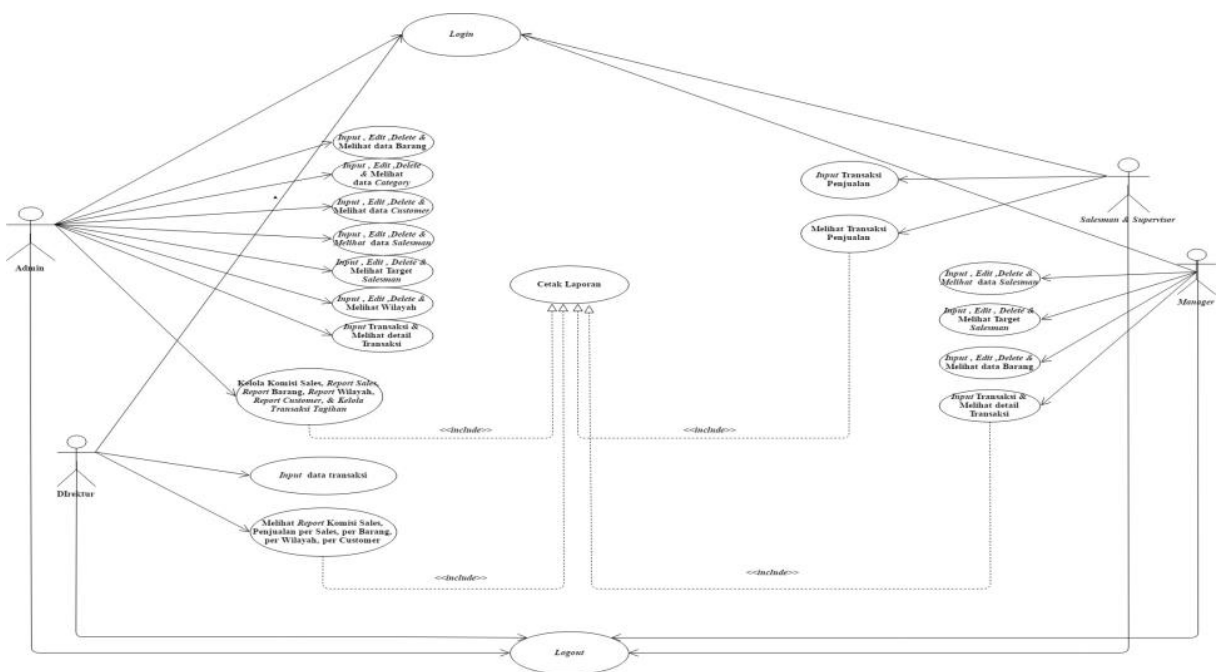

Fig 2. Usecase Diagram

\section{Use Case description}

1. Actor: Salesman \& Supervisor

Description:

a. Salesmen \& supervisors log into the system.

b. Then both salesmen and supervisors can input customer sales transactions.

c. After the ordered item is input, then can see the item that has been input in the transaction display menu.

d. Then salesmen \& supervisors can exit the application with the log out button.

2. Actor: Admin

Description:

a. Admin login to enter the system.

b. Admin can input, edit, delete and view item data.

c. Then, the Admin can input, edit, delete and view category data.

d. Admin can input, edit, delete and view customer data.

e. Admin can input, edit, delete and view salesman data.

f. Admin can input, edit, delete and view target salesmen.

g. Admin can input, edit, delete and view item data.

h. Admin can input, edit, delete and view the region.

i. Admin can also enter transactions into the system, the transaction can be in the form of a store name, transaction nominal, etc.

j. Admin can also manage sales commission reports, sales reports per item, sales reports per sales, sales reports per region, sales reports per customer and manage billing transactions which will later be printed reports.

k. Admin can exit the application with the log out button

3. Actor: Sales Manager

Description:

a. The Sales Manager logs in to enter the system.

b. Then the Sales Manager can also input, edit, delete and view salesman data.

c. The Sales Manager can input, edit, delete and view the target salesman.

d. Then, the Sales Manager can input, edit, delete and view item data.

e. The Sales Manager can also input and view transaction details.

f. The Sales Manager can exit the application with the log out button.

4. Actor: Director

Description:

a. The director must log in to enter the system. 
b. Director can input transaction data

c. After the director sees the salesman commission report, sales per salesman, sales per item, sales per region, sales per customer and also the director can print the required report.

d. The director can exit the application with the log out button.

Table 1. SWOT Analysis

\begin{tabular}{|c|c|}
\hline $\begin{array}{l}\text { STRENGH } \\
\text { 1. Can monitor sales and salesmen effectively \& efficiently. } \\
\text { 2. Can quickly get results according to user requests. } \\
\text { 3. } \quad \text { Maximizing the performance of the salesmen }\end{array}$ & $\begin{array}{l}\text { WEAKNESS } \\
\text { A lot of work is done manually so that it has a significant error }\end{array}$ \\
\hline $\begin{array}{l}\text { OPPURTUNITY } \\
\text { 1. The process of monitoring sales and salesmen systematically, } \\
\text { will lead to progress in sales and also the performance of } \\
\text { salesmen. } \\
\text { 2. A structured system makes monitoring of salesman performance } \\
\text { and sales }\end{array}$ & $\begin{array}{l}\text { THREAT } \\
\text { 1. The process of billing salesmen to customers is still insignificant } \\
\text { for the fulfillment of corporate financing. } \\
\text { The scheduled payment process becomes delayed due to } \\
\text { disruption of the company's cashflow. }\end{array}$ \\
\hline
\end{tabular}

\section{Identification of Needs}

Needs

Problem : Handling for the problem of monitoring sales and salesman performance, in this process errors often occur between the data generated and also errors in the calculation of the target salesman.

Proposal : Provided a system in the form of a monitoring system application with outputs namely reports that inform the data needed

\section{RESULTS}

\begin{tabular}{|l|l|l|l|l|}
\hline No & Problem & $\begin{array}{l}\text { Settlement } \\
\text { Approach }\end{array}$ & Solution & Model / Feature \\
\hline 1 & $\begin{array}{l}\text { In the process of making a commission } \\
\text { withdrawal report, errors often occur because } \\
\text { it is done manually }\end{array}$ & $\begin{array}{l}\text { SWOT, Needs } \\
\text { Identification, } \\
\text { Usecase }\end{array}$ & $\begin{array}{l}\text { There are features that enter } \\
\text { transaction data } \\
\text { directly accumulate sales }\end{array}$ & $\begin{array}{l}\text { Salesman } \\
\text { commission feature }\end{array}$ \\
\hline 2 & $\begin{array}{l}\text { When I want to know the achievement of sales } \\
\text { targets suddenly, sometimes it is still difficult } \\
\text { to do because it is done manually and sums up } \\
\text { the sales per sales }\end{array}$ & $\begin{array}{l}\text { SWOT, Needs } \\
\text { Identification, } \\
\text { Usecase }\end{array}$ & $\begin{array}{l}\text { The features that are } \\
\text { required for sales enter the } \\
\text { sales transaction }\end{array}$ & $\begin{array}{l}\text { Report Sales feature, which } \\
\text { means sales reports per } \\
\text { sales }\end{array}$ \\
\hline 3 & $\begin{array}{l}\text { When you want to know customer receivables } \\
\text { are sometimes difficult to do, because the } \\
\text { manual system and matching accounts with } \\
\text { original bi. }\end{array}$ & $\begin{array}{l}\text { SWOT, Needs } \\
\text { Identification, } \\
\text { Usecase }\end{array}$ & $\begin{array}{l}\text { There are features that } \\
\text { require sales to enter sales } \\
\text { transactions }\end{array}$ & $\begin{array}{l}\text { Report Customer Feature, } \\
\text { is a sales report / accounts } \\
\text { receivable per customer }\end{array}$ \\
\hline
\end{tabular}

\section{CONCLUSIONS}

The conclusion that can be drawn from the process of making a sales monitoring system is:

1. This application can help in controlling and monitoring the process of achieving salesman targets.

2. This application can facilitate each division in preparing the report so that the report becomes more effective and accurate.

3. In this application each division can find out data of goods, customer data, salesman data, target salesmen, salesman sales directly when needed.

\section{REFERENCES}

[1] T. K. Y. N. D. Junaidi, Sistem Pakar Monitoring Inventory Control Untuk Menghitung Harga Jual Efektif Dalam Meningkatkan Keuntungan, Yogyakarta: Universitas Ahmad Dahlan, 2013.

[2] L. Sulistiyowati, Panduan Praktis Memahami Analisis Laporan Keuangan, Jakarta: PT. Elex Media Komputindo, 2010.

[3] A. Sugiono, Y. N. Soenarno and S. M. Kusumawati, Akuntansi dan Pelaporan Keuangan : Untuk Bisnis Skala Kecil dan Menengah, Jakarta: Grasindo, 2010.

[4] B. Swastha, MAnajemen Penjualan Ed 3, Yogyakarta: Universitas Gadjah Mada, 2010.

[5] Mulyadi, Sistem Akuntansi, Jakarta: Salemba Empat, 2010. 